WIELKIE TEMATY KULTURY W LITERATURACH SŁOWIAŃSKICH

Slavica Wratislaviensia CLXXIII • Wrocław 2021 • AUWr No 3986

https://doi.org/10.19195/0137-1150.173.36

Data przesłania artykułu: 22.07.2019

Data akceptacji artykułu: 17.01.2020

\author{
MARTINA HALAMOVÁ
}

Uniwersytet Południowoczeski w Czeskich Budziejowicach, Czechy

\title{
Paměti českého disentu po roce 1989
}

V důsledku proměny politického systému v Československu v roce 1989 se proměnila i povaha české literatury v devadesátých letech 20. století. V nastalé proměně společnosti stála literatura před otázkou, kam zaměří svou pozornost, a bylo čím dál zřetelnější, že programem české literatury devadesátých let bude její neslužebnost. Pro dobovou literární produkci bylo důležité vymezit se vůči angažovanosti, věnovat se tematice existenciální a zdůrazňovat individuální zkušenost oproti doposud vnucovanému ideologickému zkreslení naší existence v současnosti i v minulosti. Česká literatura devadesátých let tak inklinovala zejména $\mathrm{k}$ próze sebereflexivní. Kromě fantaskních a imaginativních próz, zprostředkujících to, jaký svět subjekt utváŕí, vznikaly texty autenticitní, v nichž bylo prezentováno, jak subjekt vnímá a prožívá svět ${ }^{1}$. V obou typech próz dominovala role vypravěče a vlastní reflexe existence měla subjekt vyvést z předem daných schémat a vizí světa.

Blízko autenticitních próz stojí paměti, autobiografie či deníky, které v české literatuře $\mathrm{v}$ devadesátých letech také zaznamenaly velký boom. Bylo to dáno tím, že některé tyto texty nemohly být za předcházejícího období vydávány — můžeme v této souvislosti zmínit např́íklad Celý život Jana Zábrany, Čtrnáctero zastaveni Bedřicha Fučíka, Paměti Václava Černého, Prométheova játra Jiř́iho Koláře, paměti Josefa Hiršala s Bohumily Grögerové Let let či Nepaměti 1969-1972 a Český snář Ludvíka Vaculíka. V devadesátých letech pak vzniká řada nových ego-dokumentů známých osobností či próz využivajících některého z žánru ego-dokumenti̊. V memoárech, na něž se soustředíme, může být proces vzpomínání a podávání svědectví představen různým způsobem — od prezentování skutečnosti zevšeobecňující autorovou „kronikářskou“ perspektivou, kterou se subjekt pokouší vytvořit dojem objektivizujího vnímání skutečnosti, jako např́klad v $P a$ -

1 A. Haman, Česká beletrie 1990-1995, „Literární noviny“ 1995, č. 21, s. 4-5. 
mětech Václava Černého, až k subjektivizujícímu zprostředkovávání skutečnosti² $\mathrm{Z}$ tohoto druhého typu sebereflexivních memoárů jsem vybrala paměti herečky Vlasty Chramostové a spisovatelky Edy Kriseové, které byly vydány až v závěru onoho boomu ego-dokumentární literatury. Kniha s názvem Vlasta Chramostová vyšla v roce 1999 a Čísi svět Edy Kriseové až v roce 2004. Obě autorky patřily do okruhu pražského disentu sedmdesátých a osmdesátých let, proto je zajímavé sledovat, jak přistupují $\mathrm{k}$ tématu paměti a jak zprostředkovávají své svědectví osobní minulosti, na jejímž pozadí se teprve rodí obraz minulosti kolektivní.

Po angažování Vlasty Chramostové ve dnech srpnové okupace vojsky Varšavské smlouvy v roce 1968, kdy svému partnerovi, kameramanu Stanislavu Milotovi, pomáhala zdokumentovat tento historický milník stejně jako průběh 14. mimořádného sjezdu (vysočanský sjezd) Komunistické strany Československa v roce 1971, pozvolna přicházelo vykázání z divadelních prken. Dlouholetá herečka Divadla na Vinohradech pak potvrdila svoji osobní statečnost podpisem Charty 77. Její memoáry lze pojmenovat jako life story, která mapuje všechny podstatné etapy jejího života. V předmluvě ke knize to potvrzuje slovy, že chce „otevř́t před jinými poklop nad svou studánkou plnou krve“ ${ }^{\text {‘3 }}$. Onou studánkou jí byly tři osudové rány, které pojmenovává v knize $\mathrm{v}$ citovaném dopise z roku 1992 adresovaném Jiřině Šiklové:

Dostala jsem třetí životní ránu, ze které se nevzpamatuju a do které se probouzím tak těžce, jako když jsem přišla o syna a pak o divadlo... Ted' po dvaceti letech vzdoru a společenského vyvržení z divadelního života, mne zbavují cti. [...] Myslela jsem, že dvacet let „pokání“ za jedno slabé dopoledne před víc jak pětatřiceti lety by mohlo u přemýšlivých lidí nebo snad dokonce u křest’anů platit... Jaká pošetilost! ${ }^{4}$

Onou třetí ranou je zveřejnění takzvaného Cibulkova seznamu spolupracovníků Státní bezpečnosti, na němž bylo uvedeno i její jméno.

Vzpomínkové memoáry se vyrovnávají s touto skutečností. Pro čtenáře jsou ale zároveň důležitým svědectvím událostí spjatých s Chartou 77 a především s takzvaným bytovým divadlem Vlasty Chramostové. Premiéra jejich prvního představení - V̌̌ecky krásy světa Jaroslava Seiferta — se konala tři měsíce před zveřejněním Charty 77, většina repríz se odehrávala po něm. Autorka vzpomíná, že tato seifertovská představení se stala zároveň místem k setkání signatářu Charty, na nichž se odehrávalo něco jedinečného, kde se potkávali lidé např́ič společností a generacemi bez ohledu na světový názor, ba právě s hledáním tolerantního ohledu na něj. Čtenář se samožrejmě také dočte i o detailech a souvislostech jejich dalších inscenovaných her (Appelplatz II, Hra na Macbetha, Dávno, dávno již tomu aneb Zpráva o pohřbívání v Čechách či koláž Bít se pro ANO a pro NE též se bit). U memoárů Vlasty Chramostové je patrné, že její činy a události, na

${ }^{2}$ Viz bliže T. Kubíček, Obrana paměti: Čas a skutečnost v české literatuře sedmdesátých let, jejich povaha a di̊sledky aneb co zpưsobuje narativ, „Česká literatura“ 2004, č. 3, s. 324-353.

3 V. Chramostová, Vlasta Chramostová, Brno 1999, s. 6.

${ }^{4}$ Ibidem, s. 57-58. 
jejichž běhu se podílela, jsou vysvětlovány jednoznačně z její pozice. Chce čtenáři předat informace o světě, $v$ němž žila, a o představách, které utvářely její vědomí o světě. Chce, aby její činy nebo činy dalších disidentů, byly odhalovány z jejich diskurzu myšlení.

Sebereflexivita žánru se v memoárech Vlasty Chramostové vztahuje jednak k individuálnímu ,já“, jednak ke kolektivnímu ,já“ identifikovanému s diskursem disentu kolem Charty a bytového divadla. Její vzpomínky, tedy reprezentace událostí obsažených v její individuální paměti, představují způsob, jak si uvědomit vazbu individuálního ,já“ ke kolektivnímu vědomí dané skupiny. Jak upozornil Maurice Halbwachs, reprezentace jevů a událostí v individuálních vzpomínkách nejsou spontánní ${ }^{5}$, ale odvíjejí se v kauzalitě kolektivního myšlení. Jedinci, kteř́i vzpomínají, tedy vzpomínají jako jedinci daného kolektivu 6 . Sebereflexivní ,jáa představované na stránkách memoárů Vlasty Chramostové tak posiluje svou idenfitikaci s myšlením chartistů a zároveň posiluje či doplňuje kolektivní pamět’ dané skupiny, nebot' každá individuální pamět' představuje způsob vidění kolektivní paměti. Potřeba posilovat kolektivní myšlení může být dána vědomím, že na konci devadesátých let se již rozpadá či rozpadla sociální pamět', která by byla schopná detailně diferencovat události a vztahy mezi dobovými událostmi v normalizačním Československu, a tím je ohrožena identita individua i daného kolektivu. Zároveň její kniha pomáhá posilovat i kolektivní pamět' národní, nebot' daná epocha začíná $\mathrm{v}$ devadesátých letech spadat do náruče historie, která už na uplynulé události nahlíží zvnějšku. Historie zaznamenává švy epoch, hledá zlomy a ztrácí se tím spojitosti, které se kniha Vlasty Chramostové snaží ještě na poslední chvíli zachytit.

$\mathrm{V}$ devadesátých letech, kdy se s vizí uvést dějiny na pravou míru vydávalo velké množství ego-dokumentárních textů, reagovali literární kritici teoretickými rozvahami nad otázkou autenticity u žánru memoárů, deníků či dopisů. Petr A. Bílek v návaznosti na Paula de Mana zdůraznil, že ,autobiografický akt nemá pouze historický, ale — a především — rétorický charakter"7 a že vždy je takový text „neoddiskutovatelně textovou produkcí“, tedy „,výsledkem uspořádaného a uspořádávajícího psaní “8, kdy výběrem představovaných faktů a jejich interpretace se projevuje i záměr autora a ,já“ jakožto subjekt se stává tím, o čem se vypráví, tedy objektem vyprávění. Textové ,já“ tudíž není shodné s oním mimotextovým „já‘`9 . Jak vyplývá z Bílkova článku, cesta ke skutečné autenticitě by vedla jedině

5 M. Halbwachs, Kolektivní pamět', přel. Y. Abu Ghosh et al., Praha 2009, s. 82-83.

6 „Z této masy společných vzpomínek, opírajících se jedna o druhou, však nevystupují nutně tytéž vzpomínky každému z členů skupiny. Bez problémů můžeme připustit, že každá individuální pamět představuje způsob vidění kolektivní paměti a že tento způsob se mění v závislosti na místě, které zaujímáme, a zároveň že toto místo se mění podle vztahů, které udržuji s ostatními prostředími“. Ibidem, s. 91.

7 P. A. Bílek, Možnosti „já“: Autenticita, autobiografie, autor(ský) obraz, „Tvar“ 1996, č. 14, s. 9 .
8 Ibidem.
9 Ibidem. 
přes odosobnění sdělovaného, což v autobiografickém žánru ale není možné. Při rozvaze nad memoáry Vlasty Chramostové je patrné, že autorský subjekt ve své vizi ,autentického“ svědectví nepočítá s tím, že jí představované ,já“ se stává textovou produkcí. Naopak, paratextově, jak titulem, tak předmluvou, vymezuje svi̊j záměr vést své vyprávění přesvědčivě k autenticitě. Jistou, byt' drobnou naději, by mu mohla nabídnout Bílkova slova, že textové ,já“ je „hledáním a konstruováním možných »já«, z nichž každé je stejně pravdivé a opravdové“"10. Biografický text se stává literárním textem, ale i fiktivní reprezentace žité zkušenosti dává této zkušenosti smysl, jak prakticky doložil Ludvík Vaculík v Českém snáři či teoreticky Hayden White ve svých esejích ${ }^{11}$ či v Metahistorii.

V žánru memoárů se díky časovému odstupu, z něhož jsou události popisovány, střetávají odkazy $\mathrm{k}$ minulosti i $\mathrm{k}$ budoucnosti, nebot' tento žánr je přirozeně funkčně spjat $\mathrm{s}$ předlyotardovskou vírou, že př́iběhy paměti mohou přiblížit člověka $k$ poučení $z$ uplynulých dějin. S touto vírou se identifikovala i naše paralelní kultura ve znormalizovaném Československu a stala se součástí její identity. Nárůst ego-dokumentárních textů a autenticitních próz v sedmdesátých a osmdesátých letech v paralelní kultuře nastal v důsledku tlaku politické moci, kdy člověku zůstal pouze prostor textu prostorem potvrzujícím vlastní existenci ${ }^{12}$. Využívání žánru memoárů na konci devadesátých let či na počátku dalšího milénia poukazuje na skutečnost, že stále přetrvává kolektivní identita českého předrevolučního disentu definovaná starostlivostí o budoucí dění. Dané př́klady memoárů odkazují k této tendenci a mají demonstrovat krajní tvưrčí př́stupy, jimiž je víra v proměnu světa za pomoci memoárů realizována. Jestliže Vlasta Chramostová volí jako titul knihy vlastní jméno a paratextově tak zdůrazňuje svůj autorský záměr i horizont čtenářova očekávání, že jméno autorky garantuje pravdivost př́íběhu z naší žité minulosti, Eda Kriseová přiznává svým memoárovým textům fikční rámec a vzpomínání jí neslouží tolik k ilustraci minulosti, ale vede její pozornost k otázkám budoucnosti naší společnosti.

Časově konfrontační hledisko je podstatným rysem psaní Edy Kriseové už od jejích prvních příběhů, resp. reportáží z šedesátých let psaných pro „Mladý svět“ a později „Literární noviny“ a „Listy“. Aktéry jejích reportáží tehdy byli zejména mladí lidé, na něž česká společnost $\mathrm{z}$ různých důvodů zapomínala, a tak zde autorka svůj záměr ovlivňovat budoucí dění často deklarovala naznačenou neradostnou vizí či obavou o společenský dopad konkrétního neřešeného problému. Nejvýrazněji je pak její víra v to, že lze „pohnout“ českou společností, patrná z životopisu Václava Havla ${ }^{13}$, který lze také vnímat jako její memoáry, v nichž vytvořila své textové ,já“, když přijala roli svědka událostí spjatých s osobou Václava Havla. Její vzpomínky a vzpomínky dalších přátel jsou textovou strategií, v níž

10 Ibidem, s. 9.

${ }^{11}$ H. White, Absurdni moment v současné literární teorii, [w:] H. White, Tropika diskursu. Kulturně kritické eseje, přel. L. Nagy, Praha 2010.

12 T. Kubíček, Obrana paméti..., s. 324-353.

13 E. Kriseová, Václav Havel. Životopis, Brno 1991. 
se utváŕí lidský obraz prezidentovy osobnosti tolik odlišný od oficiálního obrazu předrevolučního prezidenta Gustáva Husáka. Autorčin pohled za oficiální portrét prezidenta, včetně jeho familiárního pojmenovávání Václav nebo Vašek, naplňuje narativní strategii představit Václava Havla jako člověka blízkého všem, člověka symbolizujícího dobově aktuální národní smýšlení ve smyslu slov nepsané hymny sametové revoluce z roku 1989, tedy písně Modlitba pro Martu „vláda věcí tvých zpět se k tobě navrátí, lide navrátí‘ “14.

Další paměti Edy Kriseové se staly již součástí jejích cestopisů, konkrétně jde o knihu Necestou slečny H. a dnešni Afrikou či cestopis z Indie nazvaným Č́ísi svět. Větší časový odstup, z něhož byla zažitá zkušenost prezentována, přiblížil totiž její cestopisy memoárům. Žánr cestopisu umožnil utvořenému textovému ,jác“ konfrontovat různé kulturní prostory a pomocí této prostorové konfrontace dospět i ke konfrontaci časové. $Z$ prezentovaných príběhů je tak patrné, že se subjekt zajímá o budoucnost naší společnosti v kosmopolitním nadhledu.

Ve vyprávěných př́ibězích z cestopisu do Indie je patrná distance mezi časem vyprávěným (čas příběhu) a časem vyprávění jednotlivých př́běhů (čas vypravěče $)^{15}$. Distance mezi subjektem a zobrazovaným světem je překrývána pouze reflexemi vyprávějícího subjektu, který tak spojuje často prostorově i časově vzdálené události pouze svou rozvahou. Textové ,jác se tudíž tolik nezdráhá přijmout svůj textový status a přiznat, že předkládaný cestopis nemůže být bedekrem o objektivním světě, jak dokládají slova z autorčina textu Čísi svět: „Existuje náš objektivní svět, nebo už skončil a všechno probíhá jenom v naší fantazii? Možná skončil, ale neví se o tom, sdělil mi filozof, když jsem ho konečně zastihla na telefonu“16. I přiznaný původní autorčin záměr psát místo cestopisu román, který ale nakonec opouští, nebot' skutečnost je dramatičtější než fikce, jak sama říká, ukazuje na autorčino vědomí, že literární příběh je obrovskou laboratoří pro pochopení světa reálného, resp. pro pochopení spojení mezi jednáním a jednajícím ${ }^{17}$. Její text Čísi svět lze tak vnímat jako řečový akt, který má ambici ovlivnit budoucí dění a očekává odpověd'.

Setkání s Indií znamená pro autorský subjekt osvobodit se od zažitých způsobů chování a myšlení. „Stereotypy zmenšují prostor, v němž žijeme, až ho docela umenší na problémy a nemoci jednoho těla a jedné duše" "18. Indie, ale i jiné kultury, jak se můžeme v knize dočíst, ji učí nehodnotit svět našimi kulturními hodnotami a stereotypy myšlení:

Pragmatik se [...] ptá: proč ti lidé od čtyř hodin ráno zpívají a nejdou raději do práce, aby si něco vydělali? Anebo: proč tu vůbec žijí, když je tu takové horko? Proč se neodstěhují?

14 M. Kubišová, Modlitba pro Martu. Hudbu složil J. Brabec, autorem písňového textu je P. Rada. Píseň vznikla v roce 1968 a stala se protestsongem proti okupaci Československa vojsky Varšavské smlouvy. Symbolem odporu se znovu stala během sametové revoluce v roce 1989.

15 P. Ricoeur, Čas a vyprávění II, přel. M. Petříček jr., Praha 2002.

16 E. Kriseová, Čísi svět, Praha 2004, s. 116.

17 P. Ricoeur, O sobě samém jako o jiném, přel. M. Lyčka, Praha 2016, s. 175-176.

18 E. Kriseová, Čísi svět..., s. 19. 
Proč se smíří se svým zařazením do nejnižších kast nebo mimo kasty a očekávají a modlí se, aby se v př́štím životě narodili v lepších podmínkách? [...] Proč nežijí jako my, proč nechtějí napodobit, nač jsme zdlouhavým vývojem přišli a poznali, že je to nejlepší ${ }^{19}$ [...] Myslím, že v Indii (vlastně ani nikde jinde, ale v Indii nejvíc) se hodnotit nedá. Jakmile si na něco utvořím názor, už ho ztrácím ${ }^{20}$.

Kriseová se snaží představit svět Indů z jejich způsobu myšlení. Obdobně to činí i při cestě Afrikou v knize Necestou slečny H. a dnešni Afrikou, když ř́ká, že je tř̌eba „myslet černě“, tedy z pohledu domorodých černochů. Snaží se tak v Africe stejně jako v Indii odhalit „,normálnost“ cizí kultury, jak Clifford Geertz definuje svůj ,zhuštěný“ popis kultury, a ukázat její přínos i pro ni samotnou, zejména pokud mluví o józe a o hinduismu v Indii.

Odhalování kultury z pohledu tamějších obyvatel a předávání těchto informací ve svých knihách čtenářum je intencionálním aktem, jímž má být podnícena možnost vzájemné komunikace a pochopení odlišných kulturních mentalit, či dokonce přijetí vlivů východní filosofie a náboženství v západním světě. Na této touze převést svůj osobní záměr na co nejširší kolektivní intenci je vystavěna hlavní idea její knihy. Odpověd’ na tento řečový akt zůstává samozřjmě v rukou každého konkrétního čtenáře, nicméně úspěšnost tohoto aktu je omezena už tím, že se západní člověk ve snaze odhalit způsob myšlení domorodých obyvatel nikdy nemůže stát domorodcem. Popisuje-li tedy indickou kulturu, popisuje ji pouze podle své představy o tom, jaké významy přikládají Indové tomu, co prožívají ${ }^{21}$. Sama to dokládá slovy: „Ale kdo je tak pokorný, aby se dokázal stát pozorovatelem? Kdo dokáže odložit svou tradici a zkušenost a dívat se, jako by svět viděl poprvé?“22. Nemožnost vystoupit ze západního způsobu myšlení dokládá mnoho autorčiných reflexí indického světa, do nichž neustále vstupuje evropský (a český) kontext. Pro ilustraci lze např́iklad uvést: „Vidím bídné chatrče podle cesty, před nimi hubení lidé zahalení v hadrech od hlavy až po bosé, tenké nohy. Stojí nehybně, nakloněni dopředu, a je v nich cosi tragicky zraněného jako v sochách Olbrama Zoubka“"23.

Knihu lze zároveň interpretovat i jako „osobní cestu“ autorského subjektu, která se nakonec může stát inspirací pro ostatní - inspirací, že kosmopolitní pohled na svět lze získat pouze na základě osobní zkušenosti, která je nepřenositelná. Eda Kriseová poprvé vycestovala v roce 1965 na pozvání své tety do Anglie, poté kromě evropských destinací následovaly cesty do Turecka, Japonska, Izraele, Spojených států amerických, Kanady, Č́ny a Thaiwanu, Indie a subsaharská Afriky či Austrálie. Kosmopolitní pohled na svět je prvním a důležitým krokem na cestě k porozumění sobě i druhým. Je jen možností, ne odpovědí na otázku, jak změnit
19 Ibidem, s. 17-18.
20 Ibidem, s. 15.
${ }^{21}$ C. Geertz, Zhuštěný popis: K interpretativní teorii kultury, [w:] idem, Interpretace kultur, přel. H. Červinková, V. Hubinger, H. Humlíčková, Praha 2000.
22 E. Kriseová, Čísi svět..., s. 15.
23 Ibidem, s. 22. 
společnost. Ale i v této možnosti a $\mathrm{v}$ odvaze lidí následovat ty, kteří se na tuto cestu porozumění již vydali, má být, jak lze z jejích cestopisů vyčíst, naznačována naděje. Eda Kriseová je vědomě tou, kdo následuje odvahu takových osobních cest - výpravou do subsaharské Afriky tak uctila památku cestovatelky slečny Hlaváčkové, která se na konci 19. století vydala po vzoru Emila Holuba do Afriky.

Oba představené sebereflexivní memoáry jsou, byt' odlišným způsobem, konstruovaným řečovým aktem, u něhož je zřetelně prezentována a autorským subjektem pojmenovávána intencionalita mluvčího. Vlasta Chramostová svým vzpomínáním oživuje či doplňuje kolektivní myšlení národa o pohled disentu. Eda Kriseová spíše rozšiřuje kolektivní paměti prostor, k němuž má být vztahována. Identitu českého člověka tak hledá i v prostoru evropském či mimoevropském. Oba texty jsou obranou paměti a kulturních vazeb k jinakosti. Jejich myšlení vyrostlé z prostředí disentu soustředěného k nutnosti být člověkem „duchovním“ (Jan Patočka) a angažovaným patrně reprezentuje tendenci české literatury na přelomu milénia, kdy se znovu diskutovala angažovanost v literatuře soustředěná $\mathrm{k}$,nápravě“ interpretace minulosti, zejména padesátých let 20 . století a období normalizace.

\section{Bibliografie}

Bílek P. A., Možnosti „já “: Autenticita, autobiografie, autor(ský) obraz, „Tvar“ 1996.

Chramostová V., Vlasta Chramostová, Doplněk/Burian a Tichák, Brno 1999.

Geertz C., Interpretace kultur, přel. H. Červinková, V. Hubinger, H. Humlíčková, Sociologické nakladatelství (SLON), Praha 2000.

Halbwachs M, Kolektivní pamět', přel. Y. Abu Ghosh et al., Sociologické nakladatelství (SLON), Praha 2009.

Haman A., Česká beletrie 1990-1995, „Literární noviny“ 1995.

Kriseová E., Čisi svět, Prostor, Praha 2004.

Kriseová E., Václav Havel. Životopis, Atlantis, Brno 1991.

Kubíček T., Obrana paměti: Čas a skutečnost v české literatuře sedmdesátých let, jejich povaha a důsledky aneb co zpưsobuje narativ, „Česká literatura“ 2004.

Ricoeur P., Čas a vyprávění II, přel. M. Petříček jr., OIKOYMENH, Praha 2002.

Ricoeur P., O sobě samém jako o jiném, přel. M. Lyčka, OIKOYMENH, Praha 2016.

White H., Tropika diskursu. Kulturně kritické eseje, přel. L. Nagy, Karolinum, Praha 2010.

\section{Memoirs of Czech Dissent after 1989}

\section{Summary}

After the fall of the communist regime, the Czech dissent participated in the creation of new ego-documents referring to the interpretation of our socialist past. In the article this issue is presented via the example of two memoirs created in the circle of dissent (the life story of the actress Vlasta Chramostová and memorial travelogues of the writer Eda Kriseová). Thinking of both writers grew out of dissent focused on the need to be a "spiritual" man (J. Patočka). Therefore, it is possible to view both self-reflective memoirs as consciously constructed speech acts to defend memory and cultural ties to otherness. It seems these texts represent the tendency of Czech 
literature at the turn of the millennium, when so called engagement in literature was discussed as a device to "correcting" interpretation of our past (especially the 1950s and the period of normalization). Methodologically the article is based mainly on texts by M. Halbwachs and P. Ricoeur.

Keywords: Czech dissent, ego-documents, self-reflective memoirs, Vlasta Chramostová, Eda Kriseová

\section{Память чешского диссидентского движения после 1989 года}

Резюме

После падения коммунистического режима чешское диссидентское движение участвовало в создании новых эго-документов, отсылающих к интерпретации социалистического прошлого. В статье данная проблематика представлена на примере двух мемуарных диссидентских текстов. Речь идёт о life story актрисы Власты Храмостовой и о путевых заметках писательницы Эды Крисеовой. Данные саморефлексивные мемуары являются сознательно конструируемым речевым актом защиты памяти и культурного взаимодействия с инакомыслием. Их мышление, сформировавшееся в диссидентской среде, сосредоточенной на необходимости быть человеком «духовным» (Я. Паточка) и участвующим в общественной деятельности, представляет собой тенденцию в чешской литературе рубежа тысячелетий, когда снова обсуждалось участие в литературе с целью «исправить» интерпретацию прошлого, особенно 50-х гг. ХХ в. и периода «нормализации». Методологическая база исследования основана на трудах М. Альбвакса и П. Рикёра.

Ключевые слова: чешское диссидентское движение, эго-документы, саморефлексивные мемуары, Власта Храмостова, Эда Крисеова

Slavica Wratislaviensia 173, 2020

(C) for this edition by CNS 